\title{
表土シードバンクを吹付けに活用した施工事例
}

\section{高橋美香 $^{1)}$ ・杉山二郎 ${ }^{122)}$ ・ 小畑秀弘 ${ }^{122)}$}

\author{
1）日本植生株式会社 \\ 2）マザーソイル協会
}

数を関東以西と関東以北に分けて集計したもので, 表-2はそ の総括表である。

1 現場 $1 \mathrm{~m}^{2}$ 当たりの木本種の平均生育本数は, 切土のり面 では関東以西で 5.5 本, 関東以北で 15.9 本, 盛土のり面では 関東以西で 7.4 本，関東以北で 8.7 本である。切土のり面で は 2.9 倍, 盛土のり面では 1.2 倍でいずれも関東以北の方が多 くなっている。

森林表土に含まれる木本種子の発芽本数は, 中村・ 中村 ${ }^{21}$ の報告によると土壤の水分条件に大きく影響を受けることか ら, 木本類の成立にはのり面土壤の保水性が大きく関与して いるものと考元られる関東以西よりも関東以北の方が平均 生育本数が多かった原因は, 関東以北において気象条件など によって乾燥が少なかったのり面が多かったためと推察され る。

切土と盛土を比較すると, 関東以西では盛土のり面, 関東 以北では切土のり面の方が多くなっている。関東以西では兵 庫の 19.0 本, 関東以北では栃木の 27.0 本, 青森の 25.3 本が 平均值を押し上げており, デー夕不足のため切土盛土の差を 比較することは適当でないと思われる。これらの平均生育本 数が多かった現場では, 湧水や北向きなどで乾燥が少ないこ とが共通している。

木本種の平均生育本数が他と比較して少なかった現場は, 広島県, 滋賀県, 愛知県でその施工条件は以下のとおりであ る。

広島県：表土をマツ枯れした林内で採取したため, 発芽可 能な種子の数が少なかったと考えられる。

滋賀県：のり面が軟岩で急勾配である。

愛知県：表土採取地が荒れた畑地の直近であったため, 畑 地雑草や帰化植物が多数生育し, 木本種を被圧し たためと考えられる。

広島県と滋賀県の事例の場合は, 表土シードバンクの混合 比率を上げる対策が必要であり, 愛知県の事例の場合は雑草 の生長を抑えるなどの対策が必要と考えられる。

全調查枠に出現した木本種の種類数は関東以西で 16 種類, 関東以北で 33 種類であった。関東以北において木本種の種 類数が多いことは，のり面土壤の水分条件が関東以西よりも 良好な現場が多かったためではないかと推察される。また, 出現箇所数が多かった種類は, 関東以西ではヌルデ, カラス

表-3, 表-4 はコドラート内に出現した種類と平均生育本 
表-1 施工地の概要

\begin{tabular}{|c|c|c|c|c|c|c|c|}
\hline & 施工場所 & 施工年月 & 切·盛 & 勾 配 & 吹付厚 & 面 積 & 調査日 \\
\hline & 長崎県 & H.15.6 & 切 & $1: 1.5$ & $t=1$ & 300 & H.15.8 \\
\hline 関 & 広島県 & H.15.4 & 盛 & $1: 1.8$ & $t=2$ & 11,480 & H.15.11 \\
\hline 東 & 兵庫県 & H.15.3 & 盛 & $1: 1.2$ & $t=3$ & 3,000 & H.15.9 \\
\hline 以 & 京都府 & H.13.7 & 切 & $1: 1.0$ & $t=3$ & 1,750 & H.14.9 \\
\hline \multirow[t]{5}{*}{ 西 } & & H.13.7 & 盛 & $1: 1.7$ & $t=1$ & 500 & H.14.9 \\
\hline & 滋賀県 & Н.14.7 & 切 & $1: 0.8$ & $t=3$ & 1,515 & H.15.7 \\
\hline & 愛知県 & H.14.3 & 盛 & $1: 1.8$ & $t=2$ & 2,000 & H1410 \\
\hline & 栃木県 & H.14.5 & 切 & $1: 0.6$ & $t=3$ & 80 & H.14.9 \\
\hline & & H.14.5 & 盛 & $1: 1.2$ & $t=1$ & 80 & H.14.9 \\
\hline \multirow{6}{*}{$\begin{array}{l}\text { 関 } \\
\text { 東 } \\
\text { 以 } \\
\text { 北 }\end{array}$} & & H.14.5 & 切 & $1: 0.8$ & $t=3$ & 120 & H.14.9 \\
\hline & 福島県 & H.14.3 & 盛 & $1: 1.5$ & $t=3$ & 200 & H.14.9 \\
\hline & 宮城県 & H.15.3 & 切 & $1: 1.2$ & $t=3$ & 850 & H.15.9 \\
\hline & & H.14.11 & 盛 & $1: 1.5$ & $t=2$ & 600 & H.15.9 \\
\hline & 岩手県 & H.14.7 & 盛 & $1: 1.2$ & $t=3$ & 700 & H.15.7 \\
\hline & 青森県 & H.15.4 & 切 & $1: 1.0$ & $t=3$ & 250 & H.15.9 \\
\hline
\end{tabular}

表-2 平均生育本数の総括表

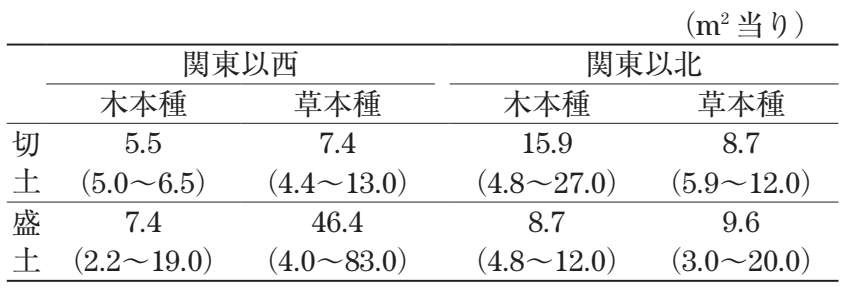

（）内の数字は平均生育本数の範囲。

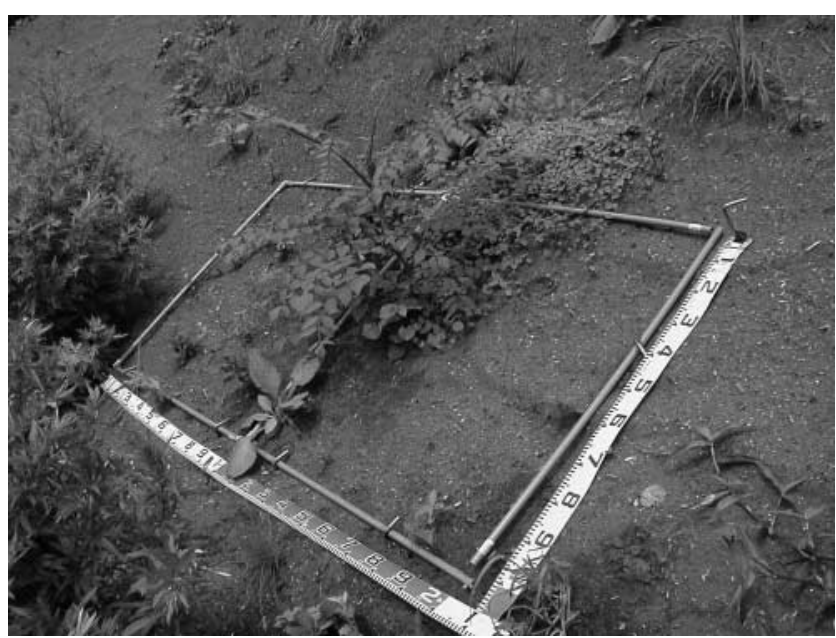

写真-1 調査枠設置のようす

ザンショウ，アカメガシワ，関東以北ではヌルデ，夕ラノキ, ヤマハギの先駆性樹種であった。

全調査枠に出現した草本種の種類数は関東以西で 30 種類, 関東以北で 46 種類であった。そのうち帰化植物の占める割

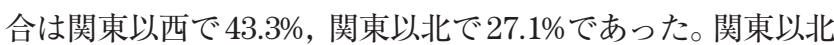
では多くの種類が出現したため全体的に帰化植物の占める割 合が低くなったと考えられる。関東以北で出現種類数が多 かったのは，のり面土壌の保水性などの発芽生育条件や表土 シードバンクに含まれる種子の種類や数などが関与している
表-3 コドラート内に出現した種類と平均生育本数(関東以西) 木本種

\begin{tabular}{|c|c|c|c|c|c|c|c|c|}
\hline $\begin{array}{l}\text { 県 } \\
\text { 吹付厚 } \\
\text { 切盛別 }\end{array}$ & $\begin{array}{c}\text { 長崎 } \\
t=1 \\
\text { 切 }\end{array}$ & $\begin{array}{c}\text { 滋賀 } \\
t=3 \\
\text { 切 }\end{array}$ & $\begin{array}{c}\text { 広島 } \\
t=2 \\
\text { 盛 }\end{array}$ & $\begin{array}{c}\text { 京都 } \\
t=1 \\
\text { 盛 }\end{array}$ & $\begin{array}{c}\text { 京都 } \\
t=3 \\
\text { 切 }\end{array}$ & $\begin{array}{c}\text { 兵庫 } \\
t=3 \\
\text { 盛 }\end{array}$ & $\begin{array}{c}\text { 愛知 } \\
t=2 \\
\text { 盛 }\end{array}$ & $\begin{array}{l}\text { 出現 } \\
\text { 箇所数 }\end{array}$ \\
\hline ネムノキ & 3.0 & 0.5 & & & & & & 2 \\
\hline カラスザンショウ & 1.0 & 0.5 & & 2.0 & 1.0 & & & 4 \\
\hline アカメガシワ & 0.5 & & 0.1 & & & 2.0 & 0.2 & 4 \\
\hline ヌルデ & & 0.5 & 0.1 & & 1.5 & 1.0 & 1.2 & 5 \\
\hline スギ & & 3.0 & & & & & & \\
\hline キリ & & 0.5 & 0.1 & 1.0 & & & & 3 \\
\hline タラノキ & & & 0.4 & & & & 0.2 & 2 \\
\hline イヌザンショウ & & & 0.1 & & & & & 1 \\
\hline ヒサカキ & & & 1.3 & 2.0 & 3.5 & 13.0 & & 4 \\
\hline アカマツ & & & 0.3 & & & & 0.2 & 2 \\
\hline ウリカエデ & & & & 1.0 & & & & 1 \\
\hline サルトリイバラ & & & & & 0.5 & & & 1 \\
\hline クロガネモチ & & & & & & 1.0 & & 1 \\
\hline コナラ & & & & & & 1.0 & & 1 \\
\hline ヒメコウゾ & & & & & & 1.0 & 0.4 & 1 \\
\hline ヤナギ属 & & & & & & & & \\
\hline 不明種 & 0.5 & & & & & & & \\
\hline 計 & 5.0 & 5.0 & 2.4 & 6.0 & 6.5 & 19.0 & 2.2 & \\
\hline
\end{tabular}

\begin{tabular}{|c|c|c|c|c|c|c|c|c|}
\hline ○イヌホオズキ & 40 & & 01 & & & & & 8 \\
\hline ○ベニバナボロギク & 1.0 & & 69.5 & & & 1.0 & & 3 \\
\hline クズ & 1.0 & & & & & & & 1 \\
\hline ○ハルノノゲシ & 1.0 & & & & & & & 1 \\
\hline カラムシ & 4.0 & & & & & & & 1 \\
\hline ○ヒメジョン & & 3.3 & 0.1 & & & & 1.5 & 3 \\
\hline ヤマノイモ & & 0.3 & & & & & & 1 \\
\hline ヒヨドリジョウゴ & & 0.5 & & & & & 9.5 & 2 \\
\hline オオバコ & & 0.3 & & & & & & 1 \\
\hline ○オオアレチノギク & & 0.3 & 0.6 & 1.5 & 0.8 & & & 4 \\
\hline メリケンカルカヤ & & & 4.7 & & & & & 1 \\
\hline ○セイタカアワダチソウ & & & 1.0 & & 0.5 & & 24.5 & 3 \\
\hline ギョウギシバ & & & 0.3 & 1.0 & & & & 2 \\
\hline メヒシバ & & & 0.1 & & & 1.0 & & 2 \\
\hline ○ダンドボロギク & & & 0.2 & & & & & 1 \\
\hline ススキ & & & 0.2 & 1.0 & & & & 2 \\
\hline スギナ & & & 0.8 & & & & & 1 \\
\hline ○ヒメムカショモギ & & & 0.5 & & & & & 1 \\
\hline ハハコグサ & & & 0.1 & & 0.3 & & & 2 \\
\hline アゼガヤ & & & 0.1 & & & & & 1 \\
\hline ○クリーピングレッドフェスク & & & 0.1 & & & & & 1 \\
\hline ○ブタナ & & & & 0.5 & & & & 1 \\
\hline メカルガヤ & & & & & 2.5 & & & 1 \\
\hline ヘクソカズラ & & & & & 0.3 & & & 1 \\
\hline ○ハルタデ & & & & & & 16.0 & & 1 \\
\hline タチツボスミレ & & & & & & 1.0 & & 1 \\
\hline ○アメリカセンダングサ & & & & & & 1.0 & & 1 \\
\hline ○ヨウシュヤマゴボウ & & & & & & & 11.0 & 1 \\
\hline スゲ属 & & & 1.6 & & & & & 1 \\
\hline 不明種 & 2.0 & 1.0 & & & & & & \\
\hline 計 & 13.0 & 4.7 & 78.4 & 4.0 & 4.4 & 20.0 & 83.0 & \\
\hline
\end{tabular}

草本種の○印は帰化植物。

のではないかと推察される。

表-5, 表-6 1 現場で観察された木本種を関東以西と関東 以北に分けて示したものである。種類数は関東以西で 34 種 類, 関東以北で 35 種類で, 両地区に共通して観察された種類 は 15 種類（ヌルデ，アカメガシワ，キリ，ネムノキ，タラ ノキ，ヒメコウゾ，コナラ，ヤマグワ，ヤマブドウ，リョウ 


\begin{tabular}{|c|c|c|c|c|c|c|c|c|c|}
\hline & & & & & & & & & \\
\hline 紧 & 石于 & 泾木 & 訬木 & 㤋木 & 㑭焉 & 呂城 & 呂城 & 月林 & 出現 \\
\hline 切盛別 & $\begin{array}{c}l=3 \\
\text { 盛 }\end{array}$ & 切 & $\begin{array}{l}l=3 \\
\text { 切 }\end{array}$ & $\begin{array}{c}l=1 \\
\text { 盛 }\end{array}$ & 盛 & $\begin{array}{l}l=2 \\
\text { 盛 }\end{array}$ & $\begin{array}{l}l=3 \\
\text { 切 }\end{array}$ & $\begin{array}{l}t=3 \\
\text { 切 }\end{array}$ & 箇所数 \\
\hline イヌシデ & 1.5 & & & & & & 0.3 & & 2 \\
\hline ウツギ & 1.5 & & & & & & & 0.3 & 2 \\
\hline ハンノキ & 3.0 & 2.0 & & & & & & & 2 \\
\hline キブシ & 4.0 & & & & & & & 1.5 & 2 \\
\hline タラノキ & 0.5 & & & & & & 0.5 & 0.4 & 3 \\
\hline ミズナラ & 0.5 & & & & & & & & 1 \\
\hline ヤマグワ & 1.0 & & & & & & & 0.1 & 2 \\
\hline ヤマハギ & & 2.0 & & & 0.2 & 0.5 & & & 3 \\
\hline ノリウツギ & & 18.0 & & & & & & & 1 \\
\hline ヤナギ & & 5.0 & & & & & & & 1 \\
\hline ネムノキ & & & 0.2 & & & & & & 1 \\
\hline アカメガシワ & & & 0.8 & 3.0 & & & & & 2 \\
\hline コウゾ & & & 2.4 & & & & 0.5 & & 2 \\
\hline ヌルデ & & & 1.2 & 2.0 & 1.0 & & 0.3 & & 4 \\
\hline マユミ & & & 0.2 & & & & & & 1 \\
\hline ヒメコウゾ & & & & 5.0 & 0.2 & & & & 2 \\
\hline クヌギ & & & & & 0.2 & & & & 1 \\
\hline ヤマブキ & & & & & 3.0 & & & & 1 \\
\hline フジ & & & & & 0.2 & & & & 1 \\
\hline コナラ & & & & & & 0.5 & 3.6 & & 2 \\
\hline サワグルミ & & & & & & 0.5 & & & 1 \\
\hline タニウツギ & & & & & & 5.5 & & & 1 \\
\hline ヤナギ属？ & & & & & & 0.5 & & 14.4 & \\
\hline バラ科？ & & & & & & 0.5 & & & 1 \\
\hline ケヤキ & & & & & & & 0.3 & & 1 \\
\hline イヌザンショウ & & & & & & & 0.3 & & 1 \\
\hline ヤマブドウ & & & & & & & 0.3 & & 1 \\
\hline クロマツ & & & & & & & 0.3 & & 1 \\
\hline イヌコリヤナギ & & & & & & & & 0.6 & 1 \\
\hline オノエヤナギ & & & & & & & & 3.9 & \\
\hline クマイチゴ & & & & & & & & 1.1 & 1 \\
\hline ミズキ & & & & & & & & 0.1 & 1 \\
\hline ヤマネコヤナギ & & & & & & & & 2.9 & 1 \\
\hline 計 & 12.0 & 27.0 & 4.8 & 10.0 & 4.8 & 8.0 & 6.4 & 25.3 & \\
\hline
\end{tabular}

ブ，クヌギ，サルトリイバラ，ヤマハギ，ハンノキ，タニウ ツギ）であった。関東以西の全ての現場で観察された種類は ヌルデ，カラスザンショウ，アカメガシワで，次いで多い種 類は夕ラノキ，キリ，アカマツ，ヤマハギ，ヤマブドウであ る。関東以北では全ての現場で観察された共通種はない。な かでも出現頻度が高い種類はヌルデ，ヤマグワ，タラノキ, ヤマハギ，ハンノキ，ヤナギ類である。

1 現場で観察された木本種の平均種類数は関東以西の切土 のり面で 10.7 種類，盛土のり面で 12.5 種類，関東以北の切 土のり面で 8.5 種類, 盛土のり面で 9.5 種類でいずれの地区も 盛土のり面の方が種類数が多くなっている。

これは盛土のり面の方が切土のり面よりも土質や勾配など 生育環境が良いためと考えられる。関東以北よりも以西の方 で種類が多かったのは，後者の現場は前者の現場よりも施工 面積が大きく，表土の採取面積が広かったことが大きな原因 の一つと考えられる。

\section{4. おわりに}

森林表土 $10 \%$ を混入して施工した植生基材吹付け工，全国 15 現場の施工初期の植生調查結果は, 急速緑化工に比べて多

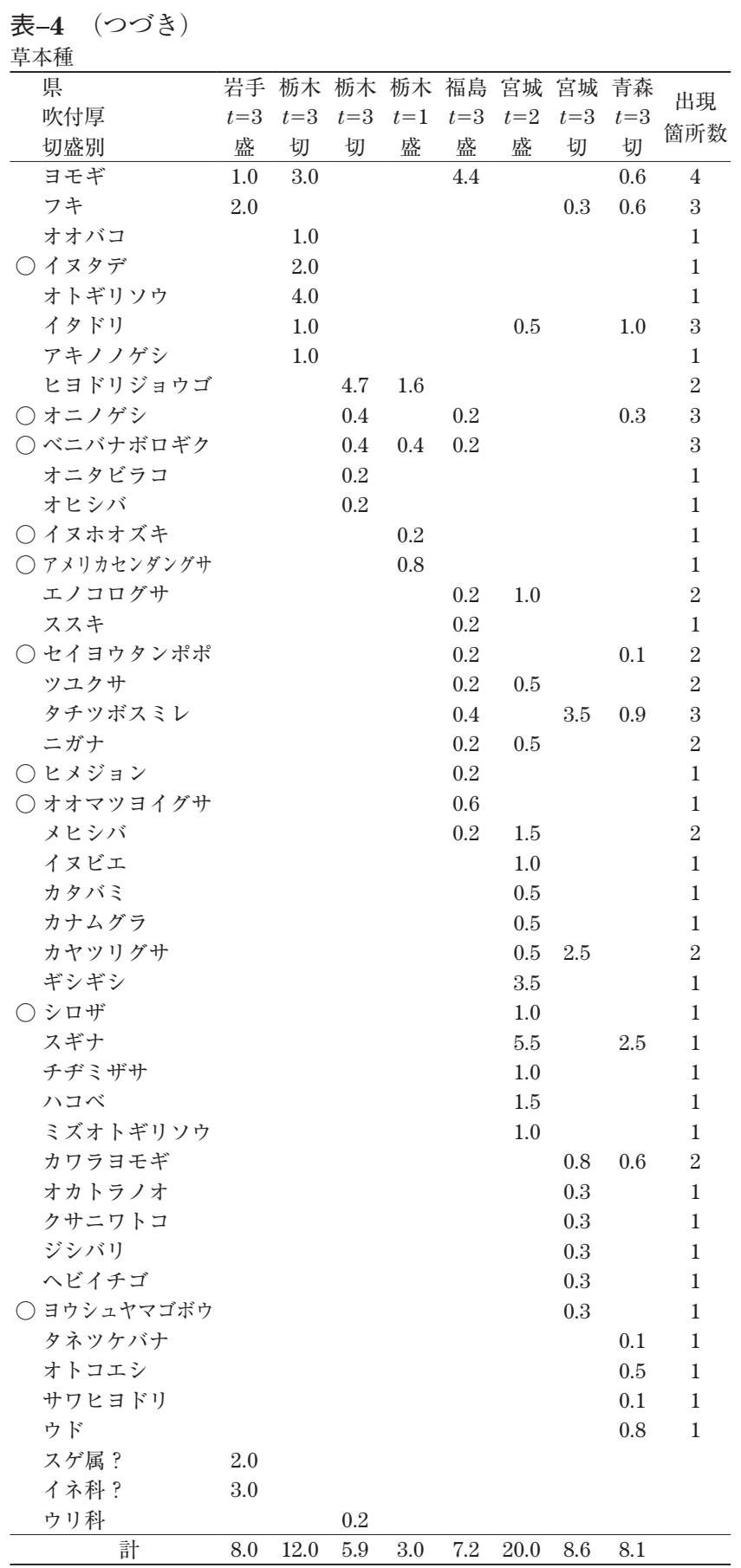

草本種の○印は帰化植物。

種の植生が生育していることが確認された。木本種は先駆樹 種が多く成立し, $1 \mathrm{~m}^{2}$ 当たりの平均生育本数は 2 本以上ある ことがわかった。関東以西と以北に大区分して木本種の平均 生育本数を比較すると, 切土のり面では 2.9 倍, 盛土のり面で は1.2倍といずれも関東以北が多くなっている。また, 全調査 枠に出現した木本種の種類数は関東以西で 16 種類, 関東以 北で 33 種類であった。

生育本数および種類数が関東以北で多かった原因は，森林 表土の中に含まれる種子の種類や数, 施工のり面の保水性な 
表-5 現場で観察された木本種（関東以西）

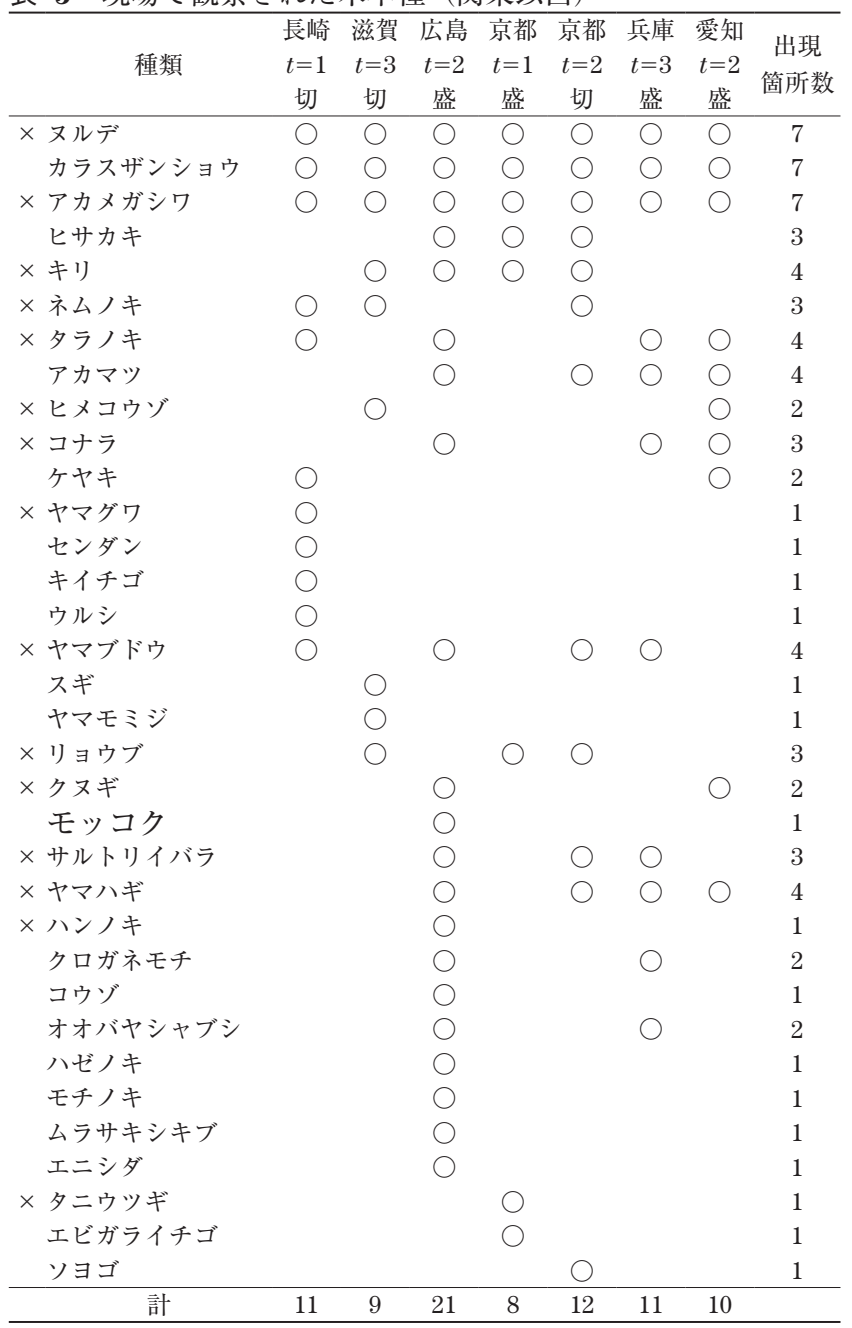

×印は関東以西と関東以北の共通種。

どの相違が考えられる。

1 現場で観察された木本種で関東以西と以北で共通に観察 された種類の割合は約 $40 \%$ であり, ヌルデ，アカメガシワ， ヤマハギ, タラノキは出現頻度が大きかった。

本調査結果から施工に当たって注意が必要な事項があるこ ともわかった。表土の採取について，マツ枯れの発生した場 所では森林表土中に木本種の数が少ないことや，荒れた畑地 のそばでは多くの畑地雑草が生育して木本種を被圧すること もある。また，のり面を構成する土質が硬く急勾配である場 合には，表土シードバンクの配合比率を上げることも必要で あると考えられる。

今回は関東以西と以北，切土と盛土のり面に大区分して比 較したが，施工実績が増えればさらに細かく地区を区分して
表-6 現場で観察された木本種（関東以北）

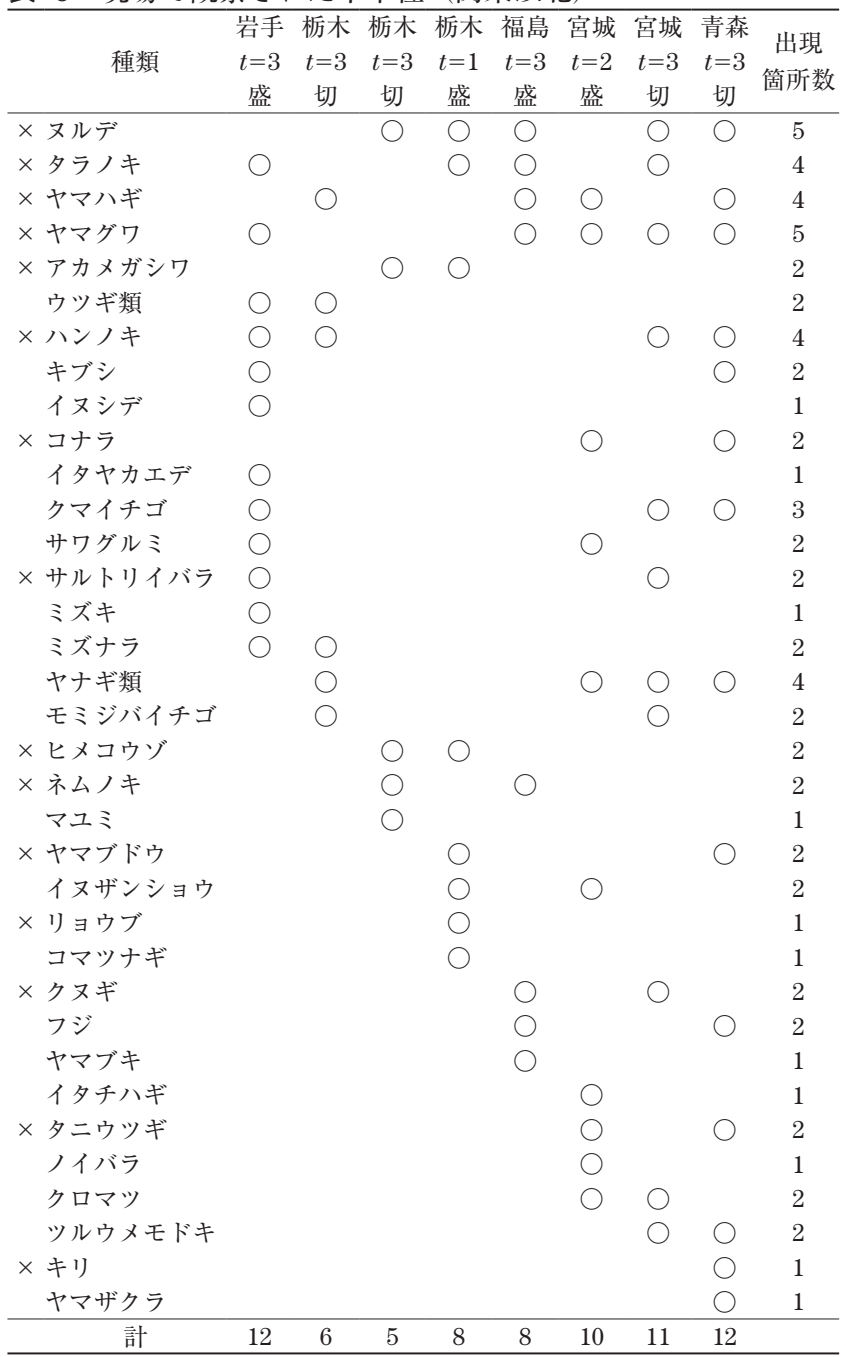

×印は関東以西と関東以北の共通種。

比較すると新たな知見が得られるのではないかと思われる。 当調査地が今後どのように推移するのか引き続き調査を実施 し，植生の推移を見守っていきたい。

\section{引用文献}

1）宮本亜紀・谷口伸二・小畑秀弘（2002）表土シードバンク を吹付けに活用した施工事例の報告，日本緑化工学会誌， 28(1): 162-164.

2）中村 剛・中村彰宏（2003）表土シードバンクを利用した 施工事例の報告, 日本緑化工学会誌, 29(1): 197-200.

(2004.9.3 受理) 